\title{
Aromatic Compounds Production by Fungal Solid State Fermentation in Pandanus tectorius Fruits
}

\author{
Sari Darmasiwi*, Oktaviana Herawati and Oktafia Citra Ningsih \\ Laboratory of Microbiology, Faculty of Biology Universitas Gadjah Mada, Yogyakarta, Indonesia \\ http://dx.doi.org/10.13005/bbra/2005
}

(Received: 10 January 2016; accepted: 01 February 2016)

\begin{abstract}
Production of microbial aromatic compounds by solid-state fermentation is increasing lately, due to the ability of microbial to use agro-industrial wastes as their substrates. The aim of this research was to know potential of aromatic compounds production by solid-state fermentation of Trichoderma viridae in Pandanus tectorius fruits. To prepare the substrates, basal mesocarp part of fruits were cut, juiced, pulps were dried and grinded until reached fine particle size. Fermentations were carried out in $250 \mathrm{~mL}$ flasks with $10^{8}$ fungal spores $/ \mathrm{mL}, \mathrm{pH} \mathrm{6.0,76,6} \%(\mathrm{w} / \mathrm{v})$ moistures at $30^{\circ} \mathrm{C}$ for 10 days. Aromatic compounds resulted from SSF were then analyzed using GC/MS. Results showed that Pandanus tectorius fruits contained total sugars $13,015 \%$, proteins $3 \%$, lipids $1,39 \%$ and moisture content were $76,6 \%$. This low sugars content in substrates seemed to be the main factor of Trichoderma viridae slow growth. There were 17 peaks of aromatic compounds detected in GC/MS, consisted of alkenes hydrocarbons (tetradecane, tertracosane, tetracosahexaene, pentadecane, hexacosane, heptadecane, and octadecane), alcohol (phenol), amide (9-octacenamide) and monoterpene aldehid (9-octadecenal). Therefore the fermentation conditions need to be further optimized to make better growth for fungi and higher aromatic compounds production.
\end{abstract}

Key words: Aromatic compounds, production, solid-state fermentation, fungi.

Production of aromatic compounds play great importance in industrial world. It is estimated that the world market for aromatic compounds reaches about 18.6 million USD in 2008, and tend to increase higher today ${ }^{1}$. Thus, it means that production of aromatic compounds seems to be promising.

Aromatic compounds can be found in perfumes, essential oils and food as flavors ${ }^{2}$. Aromatic compounds can be produced by chemical synthesis or extraction from natural material ${ }^{3}$. However, production from natural is more preferred since it is more environmental friendly and safe

\footnotetext{
* To whom all correspondence should be addressed. Fax +62 274 580839; +62 274580839 ;

E-mail : saridarma@ugm.ac.id
}

for organisms. The problem is, extraction from natural is sometimes limited by their low concentration. To overcome this, production of aromatic compounds based on microbial synthesis or bioconversion is commonly used.

Around 100 aromatic compounds have been produced by microbial fermentation. Solidstate fermentation (SSF) has been known as fermentation method that allow the utilization of agro-industrial wastes as substrates to produce aromatic compounds. In another view, it gives added-value in solving the pollution problem. Some researchers have reported the use of cassava bagasse, sugarcane bagasse, apple pomace, giant palm bran, and coffee husk as substrates for microbial aromatic production by SSF (4). Some studies reported the successful of Trichoderma 
viridae in producing aromatic compounds using sugarcane bagasse as substrates ${ }^{5,6}$, while another researches also reported the use of Trichoderma harzianum in sugarcane bagasse which both of the strain produced 6-pentyl-a-pyrone (6-PP), an unsaturated D-lactone with strong coconut aromalike ${ }^{7,8}$.

In this research we tried to explore the potential production of aromatic compounds by SSF of Trichoderma viridae in Pandanus tectorius fruits as substrates. Pandanus tectorius fruit is commonly found as wastes in south coastal of Yogyakarta Province, Indonesia since none is known about the advantages of this fruit. The fruit textures is really fibrous and causing skin itches, therefore it is inedible for human or animal consumptions (Fig.1)

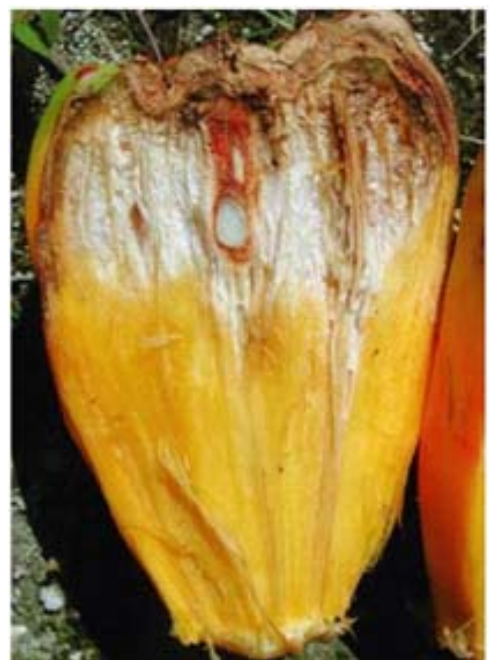

Fig. 1. Morphology of Pandanus tectorius fruit fiber. Courtessy of (9)

So far, research about production of aromatic compounds by SSF of Trichoderma viridae in Pandanus tectorius fruits as substrates has not been reported yet. We investigate and report this work with the hope that it will give contribution for the next research about production of aromatic compounds using SSF.

\section{MATERIALAND METHODS}

\section{Microorganism and inoculum preparation Fungal strain of Trichoderma viridae was}

gained from the culture collection of Food and Nutritional Centre Studies UGM, Yogyakarta. The fungal was grown and transferred periodically in Potato Dextrose Agar (PDA) slants medium then kept at $4^{\circ} \mathrm{C}$ for storage. Spore suspensions was prepared from 7-days old culture by adding $0,2 \mathrm{~mL}$ Tween 80 dissolved in sterile distilled water. The spore were then counted by Neubauer Chamber until it reached concentration about $10^{8}$ spore / $\mathrm{mL}$.

\section{Substrate preparation}

Pandanus tectorius fruits used in this research were obtained from Watu Kodok Beach, Gunung Kidul, Yogyakarta, Indonesia. Samples were taken in month of June (dry season) at 12.00 noon. Basal mesocarp which was the soft and fibrous part of the fruit were used in this research. It was cutted, juiced, then the fiber pulps were dried and grinded until reached fine particle size. Nutritional composition of the substrates were then analyzed e.g. protein (Kjedahl method), lipid (Soxhlet extractions), total sugars (Phenol sulphate) and moisture (Gravimetry method).

\section{Solid-State Fermentation (SSF)}

Solid-state fermentation were done by using $3 \mathrm{~g}$ of dry substrates in $250 \mathrm{~mL}$ flasks. The flasks were covered with cotton, sterilized in $121^{\circ} \mathrm{C}$ for 15 minutes, and inoculated with $10^{8}$ spores $/ \mathrm{mL}$. Fermentations were carried out in $\mathrm{pH}$ 6.0, 76,6\% moisture, at $30^{\circ} \mathrm{C}$ temperature for 10 days.

\section{Extraction of aromatic compounds}

Aromatic compounds was extracted by adding fermented product with $30 \mathrm{~mL}$ distilled water and further extracted with $30 \mathrm{~mL}$ dichlormethane. The mixture were then dried over sodium sulphate anhydrous before continued to GC/MS analysis.

\section{GC/MS analysis}

The GC/MS analysis was done using GC/ MS Agilent HP 5 MS UI apparatus, 30 m DB methyl silicone with $0,25 \mathrm{~mm}$ ID and $0.25 \mathrm{im}$ film thickness with helium as carrier gas. The gas velocity was $25,9 \mathrm{~cm} / \mathrm{s}$. GC oven was programmed in $70^{\circ} \mathrm{C}$ for 5 min for initial temperature until it reached $280^{\circ} \mathrm{C}$ for $34 \mathrm{~min}$. The ion temperature was $250^{\circ} \mathrm{C}$, EI ionization was $70 \mathrm{eV}$ with range scan was m/z 25-600. GC/MS data is then further processed with the available software, using NIST 12 LIB, NIST 62 LIB and WILEY 229 LIB library. 


\section{RESULTS}

The potential of material to be used as fermentation substrates is determined by their nutritional compositions. From the proximate analysis of substrates, we found that dried Pandanus tectorius fruits contained 13,015\% total sugars, 3\% proteins, 1,39\% lipids and 76,6\% moisture (Table 1).

We compared the nutritional composition between Pandanus tectorius fruit and sugarcane bagasse which were previously reported as potential substrates for aromatic compounds production by SSF of Trichoderma viridae and Trichoderma harzianum ${ }^{5-8}$. Compared to sugarcane bagasse, total sugars content in Pandanus tectorius fruits were found lower than sugarcane bagasse, while protein and moisture content of the substrates were higher than sugarcane bagasse. However, lipid content between both substrates were almost similar.

From the SSF process of Trichoderma viridae in Pandanus tectorius fruits as substrates we found at least 17 peaks of aromatic compounds which were detected by GC/MS instrument (Table 2).

Aromatic compounds identified from SSF of Trichoderma viridae were mostly consisted of alkanes (tetradecane, tertracosane, tetracosahexaene, pentadecane, hexacosane,

Table 1. Nutritional compositions in Pandanus tectorius fruits and sugarcane bagasse

\begin{tabular}{llcc}
\hline \multirow{2}{*}{ No } & Contents & \multicolumn{2}{c}{ Composition } \\
& & Pandanus tectorius fruits & Sugarcane bagasse (8) \\
\hline \multirow{2}{*}{1} & Total sugar & $13,015 \%$ & $30,9 \%$ \\
2 & Protein & $3 \%$ & $1,8 \%$ \\
3 & Lipid & $1,39 \%$ & $1,7 \%$ \\
4 & Moisture & $76,6 \%$ & $17,03 \%$ \\
\hline
\end{tabular}

Table 2. Aromatic compounds produced by SSF of Trichoderma viridae in Pandanus tectorius Fruits

\begin{tabular}{llll}
\hline No & RTime & Area (\%) & Aromatic compounds \\
\hline 1 & 15,532 & 1,86 & Tetradecane, 5-methyl \\
2 & 18,561 & 0,69 & Tetradecane, 4-methyl \\
3 & 19,146 & 1,25 & Tetradecane, 5-methyl \\
4 & 19,406 & 1,43 & $\begin{array}{l}\text { Phenol, 2,4-bis (1,1- } \\
\text { dimethylethyl) }\end{array}$ \\
& & & Octadecane \\
6 & 19,450 & 1,57 & Octadecane \\
7 & 19,480 & 0,90 & Pentadecane,2,6,10,14- \\
& 19,676 & 0,94 & tetramethyl \\
8 & 21,596 & 0,70 & Octadecane \\
9 & 22,043 & 1,63 & Heptadecane,8 methyl \\
10 & 23,379 & 3,83 & Heptadecane,8 methyl \\
11 & 23,666 & 1,28 & Heptadecane,8 methyl \\
12 & 24,849 & 0,66 & Tetracosane \\
13 & 25,871 & 4,55 & 9-octacenamide \\
14 & 25,895 & 5,14 & $9-$-octadecenal \\
15 & 27,415 & 0,72 & Tetracosane \\
16 & 27,554 & 1,46 & Hexacosane \\
17 & 29,285 & 2,43 & 2,6,10,14,18,2 - \\
& & & tetracosahexaene \\
& & &
\end{tabular}

heptadecane, dan octadecane). While other compounds such as alcohol (phenol), amide (9octacenamide) and monoterpene aldehid (9octadecenal) only found in little compositions.

\section{DISCUSSION}

The isolate of Trichoderma viridae exhibited slow growth in Pandanus tectorius solid substrates. This was probably because of low total sugar content in Pandanus tectorius which was important to provide energy sources for microbial growth and aromatic compounds production (6). According to Soares et al. (10), glucose has directional effects on microbial metabolism pathways and volatile compounds production. To overcome fungal slow growth, soluble sugars may be added to the materials in order to support microbial growth (11).

Despite low total sugar contents in substrates, protein and moisture contents of Pandanus tectorius fruits were nearly ideal for SSF growth $(50-70 \%)(12)$. So it is possible that 
Pandanus tectorius fruits may provide suitable conditions for aromatic compounds production by SSF. The optimization of fermentation conditions are needed further, in order to create better yields in microbial biomass growth and higher aromatic compounds concentration.

Aromatic compounds produced by SSF of Trichoderma viridae had almost similarities with Trichoderma atroviridae detected by HS-SPME. The microbial aromatic compounds detected in the culture samples of Trichoderma atroviridae consisted of the compound classes of alkanes, alcohols, ketones, pyrones, furanes, monoterpene and sesquiterpenes (13), however aromatic compounds from SSF of Trichoderma viridae constituted lower and different members in classes than Trichoderma atroviridae.

Aromatic compounds were also expected to be indigenous resulted by SSF of Trichoderma viridae in Pandanus tectorius fruits since it showed difference aromatic compounds compositions obtained by SSF of Trichoderma viridae and Trichoderma harzianum grown in sugarcane bagasse $(5,6,7,8)$. Therefore we concluded that aromatic compounds were potentially produced by SSF of Trichoderma viridae in Pandanus tectorius fruits.

\section{ACKNOWLEDGMENTS}

We thank to Indonesian Ministry of Research, Technology and Higher Education for State University Operational Assistance Fund 2015- Research Grants Scheme for Faculty of Biology UGM; Laboratory of Chromatography, Faculty of Pharmacy Universitas Gadjah Mada for GC/MS analysis.

\section{REFERENCES}

1. Rossi ,S.C., L.P.S. Vandenberghe B.M.P. Pereira, F.D. Gago , J.A. Rizzolo, C.R. Soccol , A.B.P. Medeiros. Improving fruity aroma production by fungi in SSF using citric pulp. Food Res. Int. 2009; 42: 484-486

2. Solange I. Mussatto, Lina F. Ballesteros, S. Martins and José A. Teixeira. In : Use of agroindustrial wastes in solid-state fermentation processes, industrial waste (Prof. Kuan-Yeow Show, Ed). ISBN: 978-95351-0253-3, InTech, Available from: http://www.intechopen.com/ books/industrial-waste/use-of-agroindustrialwastes-in-solid-state-fermentationprocesses, 2012; pp 121-140.

3. Longo, M.A. and M.A. Sanroman.Production of food aroma compounds. Food Technol. Biotechnol. 2006; 44 (3): 335-353

4. Medeiros, A.B.P., Ashok Pandey, Luciana P. S. V G M. Pastore and C R. Socco. Production and Recovery of Aroma Compounds Producedby Solid-State Fermentation Using Different Adsorbents. Food Technol. Biotechnol. 2006; 44 (1): 47-51

5. De Aráujo,A.A.D.. G.M. Pastore, and R. G. Berger. Production of coconut aroma by fungi cultivation in solid-state fermentation. App. Biochem.Biotech. 2002; 98-100

6. Fadel, H.H. M G Mahmoudb, M M S Askerb, S $\mathrm{N}$ Lotfy. Characterization and evaluation of coconut aroma produced by Trichoderma viride EMCC-107 in solid state fermentation on sugarcane bagasse. Electron. J. Biotechnol. 2015; 18 (1)

7. Carreón, L.S., K. Balderas-Ruíz, E. Galindo, M. Rito-Palomares. Production and biotrans formation of 6-pentyl-a-pyrone by Trichoderma harzianum in two-phase culture systems. Appl Microbiol.Biotechnol. 2002; 58:170-174

8. De Penha, M.P., M.H.M. da Rocha Leao, and S.G.F. Leite. Sugarcane bagasse as substrate for the production of coconut aroma for solid state fermentation. Biores. 2012; 7 (2) : 2366-2375

9. Thomson, L.A.J., L. Englberger, L. Guarino, R.R. Thaman, and C. Elevitch : Pandanus tectorius (pandanus), ver. 1.1. In: Species Profiles for Pacific Island Agroforestry (C.R. Elevitch, ed.). Hôlualoa: Permanent Agriculture Resources (PAR). http:// www.traditionaltree.org, 2006; pp 1-29

10. Soares M, Christen P, Pandey A\& Soccol CR. Fruity flavor production by Ceratocystis fimbriata grown on coffee husk in solid-state fermentation. Proc. Biochem. 2000; 35 : 857-861.

11. Manpreet, S., Sawraj, S., Sachin, D., Pankaj, S. and Banerjee, U.C. Influence of Process Parameters on the Production of Metabolites in Solid-State Fermentation. Mal. J. Microbiol. 2005; 1(2) : 1-9

12. Pandey A., P. Selvakumar, C. R. Soccol, Poonam Nigam. Solid state fermentation for the production of industrial enzymes. Curr. Sci. 2001; 77 (1) : 149-162

13. Stoppacher, N., B. Kluger, S. Zeilinger, R. Krska and R. Schuhmacher. Identiûcation and proûling of volatile metabolites of the biocontrol fungus Trichoderma atroviride by HS-SPME-GC-MS. J. Microbiol. Methods. 2010; 81 : 187-193 